\title{
Simbol-Simbol dalam Komunikasi Keluarga Beda Agama
}

\author{
${ }^{1}$ NIA KURNIATI SYAM, ${ }^{2}$ ARIFIN SYATIBI, ${ }^{3} \mathrm{MOH}$. JIBRAL IMPERIAL DAY \\ 1,2 Fak. Dakwah Unisba, Jl Rangga gading no 8 Bandung, ${ }^{3}$ Fak. Psikologi Unisba, Jl. Tamansari No.1 Bandung \\ email: ${ }^{1}$ nia_syamday@yahoo.com; ${ }^{2}$ jibralimperialday@gmail.com
}

\begin{abstract}
This article is one of the research having the plurality of cultural ethnic and religion background. The religion identity is an important dimension for all societies. The goal of the article is to analyze the role of interpersonal communication in a family with different religion, analyze the meaning of symbols in an interaction within the family with different religion, analyze the supporting and restricting communication factors in a family with different religion. Several perspectives were used as theoretical framewaork, i.e Phenomenology, and Cross Cultural Communication. This reseach employed in-depth interview and observation as data collecting technique. The role of interpersonal communication in a family with different religion cannot be separated from initiation, experiment, intensification, integrity, bond and the role of communication effectiveness such as supportiveness, empathy, objectiveness and equality. The meaning of communication symbols in a family with different religion is due to language, rituals, national days, food, and dress. The supporting factors are respect each other, protect, tolerance, cooperation, and mutual cooperation. Whereas the restricting factors of interpersonal communication in a family with different religion, are avoiding the dialogue about faith, freedom, and religion education for children.
\end{abstract}

Keyword: cross-religion communication, communication symbol

\begin{abstract}
Abstrak. Artikel ini merupakan salah satu bagian dari hasil penelitian yang dilatarbelakangi oleh pluralitas etnis budaya dan agama. Identitas agama merupakan dimensi yang penting bagi sebuah masyarakat. Tujuan artikel ini adalah untuk menganalisis peran komunikasi antarpersona dalam keluarga yang berbeda agama, menganalisis makna simbol-simbol dalam berinteraksi pada keluarga berbeda agama, menganalisis faktor-faktor pendukung dan penghambat komunikasi dalam keluarga berbeda agama. Untuk memahami fenomena tersebut maka digunakan berbagai teori sebagai kerangka pemikiran yaitu fenomenologi dan pendekatan komunikasi antarbudaya. Teknik pengumpulan data dilakukan melalui wawancara mendalam dan observasi. Peran komunikasi antarpersona yaitu dalam keluarga berbeda agama tidak terlepas dari inisiasi, eksperimen, intensifikasi, integrasi, ikatan dan peran efektivitas komunikasi yang baik seperti saling mendukung, empati, objektif dan kesamaan. Makna simbol dalam komunikasi keluarga beda agama yaitu tentang bahasa, ritual, hari-hari besar, makanan, pakaian. Faktor pendukung yaitu saling menghormati, mengayomi, dan toleransi, bekerjasama gotong royong. Faktor penghambat komunikasi antarpersona dalam keluarga beda agama, yaitu menghindari pembicaraan mengenai keyakinan, kebebasan pendidikan agama anak.
\end{abstract}

Kata kunci: komunikasi lintas agama, simbol komunikasi

\section{Pendahuluan}

Masyarakat Kabupaten Cirebon hidup berdampingan dan berinteraksi, berkomunikasi satu sama lain, meskipun memiliki multi-agama dan kepercayaan, seperti Islam, Katolik, Protestan, Hindu, Budha, dan aliran kepercayaan, itulah pluralitas agama di era globalisasi yang menjadi karakteristik dari bangsa Indonesia yang heterogen. Hal ini tidak dapat dipungkiri, pluralitas agama memiliki potensi dan peran sangat besar dalam proses integrasi dan pembangunan daerah Cirebon. Di samping itu, pluralitas agama juga mengandung potensi terjadinya konflik dan disintegrasi bangsa, ketika melihat masing-masing agama memiliki klaim kebenaran absolut dan muatan emosi keagamaan yang menjadi dasar

Received: 3 Agustus 2015, Revision: 11 Oktober 2015, Accepted: 18 Desember 2015

Print ISSN: 0215-8175; Online ISSN: 2303-2499. Copyright@2015. Published by Pusat Penerbitan Universitas (P2U) LPPM Unisba Terakreditasi SK Kemendikbud, No.040/P/2014, berlaku 18-02-2014 s.d 18-02-2019 
interaksi primer.

Konflik atas dasar perbedaan agama bisa disebabkan, oleh ajaran agama itu sendiri, kualitas moral-spiritual penganutnya, maupun latar belakang budaya, seperti kultur patriarkal atau ikatan primordial yang masih kuat. Selain itu, pemicu konflik yaitu penyiaran agama, perkawinan antar pemeluk agama yang berbeda, pengangkatan anak, pendidikan agama, transparansi informasi keagamaan, pendirian rumah ibadah, penodaan agama. Secara struktural ,perbedaan agama tersebut berkaitan erat dengan rasa insecurity dalam bidang sosial, ekonomi, politik, dan budaya.

Sebuah keluarga yang mempunyai 7 orang anak yang terdiri atas 4 perempuan dan 3 anak laki-laki (sudah dewasa) di antara mereka ada yang beragama Islam maupun Kristen. Hidup bersama. Ketika berbicara mengenai keluarga, ia mengatakan selama berkeluarga tidak ada hal yang memicu konflik, mengenai pendidikan anak ketika masih kanak-kanak dibebaskan mau sekolah agama sore (Islam) atau sekolah Rabu (sekolah yang dikelola oleh misi Kristen). Kepala keluarga Kristen beristri Islam ini pun dipercaya sebagai Babinsa di desa Sidawangi, yang mayoritas penduduknya beragama Islam (wawancara dengan informan, Jan 2014) hal ini merupakan fenomena unik.

Dengan segala kekurangan dan kelebihannya, kerukunan umat beragama di Indonesia dinilai oleh dunia internasional sebagai yang "terbaik" ujar menteri Agama yang pada waktu itu masih Maftuh Basyuni dalam sambutan tertulisnya yang dibacakan kepala Puslitbang kehidupan Keagamaan Depag Abdul Rahman Mas'ud dalam siaran pers yang diterima dari Pusat Informasi Depag di Jakarta (PR. Kamis 28/5/2009).

Hal ini sesuai dengan salah satu prototype masyarakat Kabupaten Cirebon memiliki multi agama dan kepercayaan, hidup berdampingan dan berkomunikasi satu dengan lainnya. Mayoritas masyarakat Cirebon menganut agama Islam, mereka hidup berdampingan dengan masyarakat non agama Islam, termasuk beberapa keluarga berbeda agama dalam satu keluarga yang berada di Desa Sidawangi, yang menjadi lokasi penelitian. Sedangkan informan dalam penelitian ini sebanyak 6 orang keluarga berbeda agama. Penelitian kualitatif ini menggunakan metode fenomenologi dengan teknik pengumpulan data melalui wawancara mendalam dan observasi.
Fenomena di atas menarik penulis untuk meneliti lebih dalam bagaimana peran komunikasi antarpersona dalam keluarga berbeda agama tersebut.

Berdasarkan fenomena di atas, maka peneliti memfokuskan masalah penelitian sebagai berikut: Peran komunikasi antarpersona pada keluarga berbeda agama; faktor-faktor yang pendukung dan penghambat kerukunan dalam keluarga berbeda agama, langkah-langkah meminimalisasi hambatan tersebut.

Adapun penulisan artikel ini untuk menganalisis peran komunikasi antarpersona pada keluarga berbeda agama; faktor-faktor pendukung dan penghambat kerukunan dalam keluarga berbeda agama; langkah-langkah meminimalisasi hambatan tersebut. Berbagai kajian tentang komunikasi keluarga berbeda agama masih jarang, selain rentan, karena melibatkan ranah pribadi secara privasi. Beberapa penelitian tentang komunikasi antarpersona yang telah dilakukan yaitu:

Nia Kurniati, 2001, Tesis Unpad, meneliti "Pengaruh Karakteristik Sosiodemografi dan Jarak Sosial terhadap Efektivitas Komunikasi Antaretnik" menyimpulkan, apabila karakteristik sosiodemografi semakin rendah dan jarak sosial lebih ditingkatkan lagi, maka akan semakin meningkatkan efektivitas komunikasi antaretnik. Artinya, komunikasi antaretnik tidak hanya dipengaruhi oleh pendidikan dan pendapatan, tetapi samasama dipengaruhi oleh jarak sosial seperti cenderung memilih suami/istri, mantu, bertetangga, memilih kawan dari etniknya sendiri. Interaksi etnik Tionghoa Muslim dan etnik Sunda dapat efektif jika unsur-unsur pendidikan dan pendapatan diperhatikan dan dapat ditingkatkan dalam komunikasi antaretnik. Ali Masykur, 2005, IAIN Sultan Maulana Hasanuddin, Banten, tentang "Pola Komunikasi Antar Umat Beragama (Studi dialog Umat Islam dan Kristen di Kota Cilegon Banten)" menyimpulkan, untuk mencapai kehidupan beragama yang dinamis itu tidak bisa tidak, para penganut agama harus menapaki jalan menuju yang satu dengan menghormati perbedaan-perbedaan agama, pluralitas agama lewat keterbukaan terhadap agama yang lain untuk saling mengenal dan saling memahami timbal balik, seperti melalui proses dialog antaragama. Dialog antaragama merupakan titik pertemuan para penganut berbagai agama. Kerena itu, tidak terelakkan jika fakta pluralitas agama akan berujung pada dialog antaragama (Article: Unnual 
Conference, 2010).

Dalam memahami fenomena artikel ini, maka digunakan berbagai teori sebagai kerangka pemikiran, yaitu fenomenologi dan komunikasi antarbudaya dari Martin \& Nakayama sebagai kerangka pemikiran.

\section{Fenomenologi: Sebuah Perspektif}

Penelitian ini menggunakan metode fenomenologi, yang pertama kali diperkenalkan oleh Edmund Husserl (18591938) metode penelitian ini digunakan untuk mengungkapkan bagaimana komunikasi suami istri pada keluarga beda agama, melalui pernikahan antarbudayanya adalah metode penelitian yang berparadigma subjektif interpretif, yaitu penelitian kualitatif dengan pendekatan fenomenologi. Dalam penelitian ini, peneliti berusaha untuk "mereduksi" kesadaran informan dalam memahami bagaimana fenomena komunikasi antar suami istri beda agama dalam mengonstruksi nilai-nilai komunikasi keluarga beda agama tersebut. Pemikiran fenomenologi berfokus pada pengalaman personal individu.

Realitas adalah bukan suatu yang sederhana yang untuk pemahamannya tidaklah cukup hanya berbekal pengamatan sepintas. Realitas mengenai dunia fenomena dan noumena seperti yang disebutkan Immanuel Kant.Dunia fenomena menurut Mulyana (2001: 19), adalah dunia yang dialami oleh manusia dengan seluruh pancaindranya. Karenanya, jika kita merujuk pada Sudikin (2003:3),

masalah dunia sosial keseharian dan senantiasa merupakan suatu yang intersubjektif dan pengalaman penuh makna. Dunia fenomena adalah dunia di mana informasinya diperoleh dari pancaindra kita di mana manusia berperan aktif dalam membangun dan menafsirkan sensasi-sensasi inderanya menjadi makna.

Sebagai sebuah pengalaman sadar maka dalam perkawinan beda agama tersebut terjadi sebuah bentuk kesadaran yang menghasilkan pemaknaan intersubjektif. Dengan melibatkan pengujian yang teliti dan mendalam pada kesadaran pengalaman manusia, hal ini sesuai dengan konsep utama dalam fenomenologi, yakni makna, dan merupakan isi penting yang muncul dari pengalaman kesadaran manusia. Pemahaman tersebut sejalan dengan apa yang menjadi telaah fenomenologi yang diuraikan Littlejohn (2005: 38). Ia mengatakan bahwa people actively interpret their experience and come to understand the world by personal experience with it. Dalam konteks tersebut, terlihat bahwa pengalaman seseoarang sangat terkait dengan bagaimana ia secara pribadi menginterpretasikan makna yang di dapatnya sebagai hasil interaksi dengan lingkungan.

Di sisi lain, Kuswarno (2009:25) menjelaskan dengan tegas bahwa,

sesungguhnya pengalaman sadar memang menjadi titik awal dalam pembahasan fenomenologi, namun pengalaman sadar yang bagaimana yang menjadi objek kajian fonomenologi? Dalam hal ini, sebuah kesadaran dari pengalaman (awareness of experience) didefinisikan sebagai keadaan yang memberikan sudut pandang pengalaman orang pertama. Jadi, fenomenologi berusaha untuk memahami bagaimana seseorang mengalami dan memberi makna pada sebuah pengalaman, karena dunia sosial keseharian senantiasa merupakan suatu yang intersubjektif dan pengalaman selalu banyak makna.

Tulisan melihat berbagai pengalaman para informan keluarga berbeda agama, ini sejalan dengan pendapat Schutz yang menyatakan bahwa "tugas fenomenologi adalah menghubungkan antara pengetahuan ilmiah dengan pengalaman sehari-hari, dan dari kegiatan di mana pengalaman dan pengetahuan itu berasal. Dengan kata lain, mendasarkan tindakan sosial pada pengalaman, makna, dan kesadaran (Kuswarno, 2009:17)

\section{Komunikasi Antarbudaya}

Penelitian ini menggunakan teori Komunikasi Antarbudaya (Martin \& Nakayama, 2004:162), yang menjelaskan bagaimana komunikasi antarpribadi-berbeda budaya dalam sebuah keluarga yang berbeda agama. Sedangkan peran komunikasi antarpribadi dalam keluarga yang berbeda agama tidak terlepas dari (1) inisiasi; (2) eksperimen; (3) intensifikasi; (4) integrasi, dan (5) ikatan. Tahapan-tahapan hubungan lebih akrab ini menjadi ranah penelitian yang diambil dari Knap (1978).

Pendekatan ini amat sesuai dengan unsur-unsur penelitian. Sedangkan aplikasi teori lainnya yaitu tentang peran efektifnya sebuah komunikasi dalam keluarga diambil dari pendapat De Vito yang mengemukakan beberapa faktor penentu efektivitas komunikasi antarpribadi, yakni: keterbukaan; empati; perasaan positif; dukungan; dan keseimbangan (Liliweri, 2001:171).

Beberapa ahli berusaha merumuskan kompetensi komunikasi antarbudaya, Kim menawarkan sebuah definisi detail mengenai kompetensi komunikasi antarbudaya 
yaitu keseluruhan kapabilitas internal dari seseorang untuk menghadapi ciri-ciri dari tantangan yang sering terjadi saat komunikasi antarbudaya terjadi, yaitu, perbedaan budaya, dan ketidaksamaan, sikap intergrup. Jadi, dari pengertian ini bisa dipahami untuk menjadi komunikator yang kompeten, kita harus memiliki kemampuan untuk menganalisis situasi dan memilih mode dari perilaku yang tepat (Samovar, dkk, 2007: 314).

\section{Peran Komunikasi Antarpribadi dalam Keluarga Berbeda Agama}

Keunikan yang terjadi pada hubungan perkawinan adalah meskipun banyak perbedaan antara laki-laki dan perempuan seperti perbedaan emosional, lingkungan, genetis dan kepribadian, selalu ada perkawinan yang berhasil. Perkawinan tersebut dinikmati oleh laki-laki dan perempuan sebagai suamiistri yang berbahagia. Mayoritas pasangan yang menikah memiliki tujuan utama hidup bersama, berbagi dukungan fisik dan komunikasi tentang berbagai kesenangan dan masalah (Osborne, 1988).

Dalam Al-Qura'nul Karim, Surat ArRum, 21:

"Dan diantara tanda-tanda (kebesaran)-Nya ialah Dia menciptakan pasangan-pasangan untukmu dari jenismu sendiri, agar kamu cenderung dan merasa tentram kepadanya, dan Dia menjadikan diantaramu rasa kasih sayang. Sungguh, pada yang demikian itu benar-benar terdapat tanda-tanda (kebesaran Allah) bagi kaum yang berpikir." (QS Ar-Rum [30]:21)

Keunikan hubungan manusia tidak terlepas dari peran dan fungsi komunikasi antarpribadi yaitu membangun kontak dengan orang lain, untuk kemudian memberikan kesamaan dalam makna pesan, maka komunikasi antarpribadi bisa dikembangkan lebih luas akibat orang menukarkan pengalamanya. Demikian pula dalam kontek sebuah perkawinan tidak terlepas di dalamnya komunikasi yang inten. Dalam komunikasi antarpribadi, dapat terlihat secara langsung aksi maupun reaksi verbal maupun nonverbal seseorang demikian pula dalam keluarga (suami-istri, maupun anak).

Pasangan suami-istri berbeda agama ini menyadari bahwa pemerintah melarang pernikahan berbeda agama, namun mereka "mengelabuinya" dengan pindah agama dari salah satunya, baik Islam ke Kristen, atau Kristen ke Islam, sehingga dapat diakui sebagaimana Undang-Undang Perkawinan dalam Pengantar Komnasham, Pernikahan
Beda Agama: xv (UU Nomor 1 Tahun 1974 tentang Perkawinan Beda Agama, Pasal 2 ayat (1), disebutkan, "Perkawinan adalah sah, apabila dilakukan menurut hukum masingmasing agamanya dan kepercayaannya itu"). Peneliti menemukan penjelasan semua informan keluarga berbeda agama, ketika mereka akan melangsungkan perkawinan, mereka berpindah ke salah satu agama, baik Islam-Kristen atau sebaliknya, setelah melangsungkan pernikahan beberapa minggu, atau ada yang beberapa bulan saja mereka kembali lagi kepada agama semula.

Dari perkawinan ini terbentuklah keluarga, keluarga merupakan salah satu institusi sosial budaya yang mempunyai tugas untuk meneruskan budaya dari satu generasi ke generasi berikutnya (Samovar at al, 2010:64).

Pada abad ke 17, Charles Colton memperkenalkan pentingnya keluarga, dalam tulisannya "Keluarga merupakan unit paling dasar dari pemerintahan, sebagai komunitas pertama di mana setiap orang berhubungan dan otoritas pertama di mana seseorang belajar untuk hidup, keluarga membentuk nilai paling dasar suatu masyarakat" (Samovar, 2010: 64).

Penelitian ini dilakukan pada keluarga inti. Keluarga inti disebut "keluarga dua generasi," merupakan pola yang paling umum di negara yang berkembang seperti di Indonesia. Nilai budaya yang ada dalam keluarga inti ini adalah pola asuh anak, dimana dalam pola asuh tersebut interaksi orang tua dengan anak secara intens. Penelitian ini tidak meneliti tentang sebuah keluarga besar walau secara sepintas terungkap, di mana keluarga besar terdiri atas keluarga inti terkait berkumpul ke dalam sebuah unit domestik yang lebih besar. Lebih dari orangtua dan anak-anak: kadang juga termasuk anakanak, sepupu, bibi, paman, kakek-nenek, dan bahkan buyut (Samovar, 2010:67).

Keluarga inti ini menjadi subjek penelitian di mana suami istri yang berbeda agama. Komunikasi antarpribadi dalam hal "keterbukaan" mereka selalu menghindari pembicaraan mengenai keyakinan (agama) masing-masing pihak. Namun, toleransi, support dan kebersamaan, objektif dalam hal-hal sosial, kebersamaan selalu dijunjung tinggi. Seperti saling memahami, saling menghormati, saling mendorong untuk taat dalam menjalankan agamanya masing-masing saling pengertian satu dengan lainnya dalam hal perbedaan terutama dalam keyakinan, 
sedangkan hal-hal sosial kemasyarakatan mereka saling menghormati atas perbedaan keyakinan. Keluarga saling mendorong antara suami istri dalam hal menjalani hak dan kewajiban sebagai umat beragama.

Dalam hal pendidikan agama, keluarga berbeda agama tidak tegas dalam memberikan arahan untuk mempelajari salah satu agamanya. Pasangan suami-istri yang berbeda agama saling mendorong pasangannya jika salah satu dari mereka merayakan hari besar, melakukan kebiasaan ritual, baik harian, mingguan, dan harihari besar agama lainnya. Dengan saling mengingatkan, saling menasihatkan, supaya teguh dengan keyakinan masingmasing. Saling mengantarkan ke tempat ibadah mereka, dengan mengindahkan aturan-aturan yang disepakati mereka dan masyarakat secara umum. Mereka mempunyai kemampuan untuk mengolah kecemasan, kemampuan untuk berempati, kemampuan untuk mengadaptasi perilaku, kemampuan untuk membuat penjelasan dan prediksi yang akurat (Gudykunst \& Kim, 2003: 276-292).

Dalam keseharian, keluarga berbeda agama dalam bahasa yang digunakan seperti mengucapkan "salam" ketika bertemu dan sering mengucapan salam seperti Muslim seperti ucapan "assalamu'alaikum" bila salah seorang dari mereka bertemu. Bahkan ,ucapan "astaghfirulloh", bila melakukan kesalahan yang tidak disengaja dan ucapan "alhamdulillah" sering mereka ucapkan ketika mereka mendapatkan kebahagiaan. Mereka mengetahui artinya dari masing-masing kata tersebut namun makna yang terkandung lebih jauh dari masing-masing kata tersebut tidak dipahami.

Menurut Burke dalam Intercultural Communication in Context, kelompok budaya memengaruhi proses dimana persepsi dari realitas diciptakan dan dibangun: "Semua komunitas di semua tempat dan setiap waktu memanifestasikan pandangan mereka sendiri terhadap realitas yang mereka lakukan. Bagaimanapun, kita mungkin saja bisa mengatakan bahwa komunikasi membantu menciptakan realitas budaya dari suatu komunitas (Martin \& Thomas, 2007:92), selama proses interaksi, terdapat pertukaran motif antara para aktor yang terlibat, demikian juga pada keluarga berbeda agama dalam berkomunikasi membantu menciptakan realitas budaya dari suatu komunitas keluarga berbeda agama, termasuk bahasa yang digunakan keseharian. Dan hal ini pun melahirkan komunikasi antarbudaya karena dalam proses komunikasi mereka berinteraksi dalam keluarga dengan pasangan yang berbeda kebiasaan baik ritual dan simbolsimbol keagamaaan yang berbeda dimana komunikasi antarbudaya adalah komunikasi yang terjadi di antara orang-orang yang memiliki kebudayaan berbeda (bisa ras, etnik, atau sosioekonomi, atau gabungan dari semua perbedaan ini). (Tubb \& Moss, 2001:237).

Peran komunikasi antarpribadi pada keluarga berbeda agama sangat baik, melihat dari inisiasi kedua belah pihak ketika bertemu dan ketika berpisah saling bersapa, dapat mengungkapkan perasaan persamaan dan perbedaan kepentingan seperti dalam kehidupan sehari-hari mengungkapkan informasi mengenai pasangannya, dalam era komunikasi saling ber-SMS jika berjauhan dan biasa saling terbuka untuk membuka handphone masing-masing, walaupun ada salah satu keluarga yang tidak mempunyai alat komunikasi jarak jauh seperti handphone. Kemudian, keluarga berbeda agama ini menciptakan rasa bersama terlihat dari cara mereka berbicara selalu bertutur dengan kalimat "kami sama-sama pergi..."Hal ini menandakan bahwa mereka satu unit bukan individu yang terpisahkan. Dan mereka terikat ketika keduanya masuk pada suatu ritual masing-masing yang secara formal mengakui hubungan jangka panjang, yaitu perkawinan. Hal ini sejalan dengan teori hubungan yang diungkapkan oleh Knap (1990), yaitu tahapan-tahapan hubungan akan lebih akrab dengan yang lainnya melalui insiasi, eksperimen, intensifikasi, integrasi, dan ikatan.

Pendidikan agama bagi anak-anak dalam keluarga beda agama, tidak dilakukan dengan mengarahkan dan menekankan mempelajari salah satu agama, namun mengarahkan kepada keduanya sebagai sebuah pondasi hidup, seperti yang dilakukan salah satu informan walaupun ia menganut agama Kristen tetapi kedua anaknya diberikan pendidikan nonformal dengan mengikuti pendidikan di madrasah (agama Islam) sore hari dan juga di berikan pendidikan di sekolah Rabu, yang dibimbing oleh rohaniawan di gereja setempat. Mengenai pendidikan agama, mereka menyerahkan kepada anakanak mereka masing-masing jika kelak sudah dewasa dapat menentukan pilihan mereka sendiri dengan penuh tanggung jawab. 
Pendidikan agama dalam keluarga berbeda agama "tidak memaksakan kehendak" (supaya agama-keyakinan orang tua harus sama dengan anak) dan "semua agama baik" (disilahkan memilih menurut kehendak masing-masing keyakinannya) kata kunci inilah yang membuat mereka tidak ada komunikasi yang bergejolak menurut mereka.

Hal tersebut senada seperti yang diamati oleh Rodrigguez dan Olswang, "Masyarakat berbeda, diantara maupun di dalam budaya, konsepsi mereka tentang karakter yang diharapkan dari anak-anak, oleh karena itu, kepercayaan dan nilai yang dianut oleh orang tua layak berbeda, karena orangtua mengembangkan karakter anak-anak mereka sesuai dengan apa yang digambarkan dalam budayanya" (Samovar, 2010: 74).

Peranan keluarga tidak terlepas dari bentuk dan tipenya, memiliki peranan yang sama. Peranan ini bertujuan untuk mengajarkan budaya pada anggota keluarga yang baru sejak lahir, tentang apa yang mereka perlu ketahui untuk dapat bertahan hidup dan tinggal dalam masyarakat yang harmonis. Dalam pengertian ini, kebudayaan menjadikan keluarga sebagai institusi sosial untuk mengajarkan orang-orang "dalam cara berpikir dan bertindak yang terpola dan dapat diprediksi menyangkut kepercayaan, nilai, tingkah laku, norma yang mengatur aspek vital dari kehidupan suatu kelompok dan memiliki fungsi sosial." (Samovar, 2010:70). Menyimak penuturan dan penjelasan dari informan keluarga berbeda agama, yaitu menegnai pendidikan diserahkan kepada individu, sedangkan orang tua hanya memberikan ketegasan bahwa jika sudah mempercayai suatu keyakinan maka harus dilaksanakan dengan penuh tanggung jawab, artinya lakukan dengan sepenuh hati.

Adapun simbol-simbol yang terdapat pada keluarga berbeda agama seperti; symbol ritual keagamaan; kalung salib, pakaian adat kampret hitam, gambar masjid, gambar gereja, pohon natal, pernak-pernik natal, peralatan salat baik yang dipakai

Tabel 1

Makna Simbol-Simbol dalam Komunikasi Antarpribadi pada Keluarga Berbeda Agama.

\begin{tabular}{|c|c|}
\hline Islam & Kristen-Katolik \\
\hline $\begin{array}{l}\text { - Ritual: salat lima waktu, salat hari Jumat, puasa } \\
\text { bulan Ramadhan, Hari Raya Iedul Fitri dan Hari } \\
\text { raya Iedul Adha, pengajian di masjid, bedug untuk } \\
\text { menandakan waktu salat } \\
\text { - Hari besar: tidak ikut perayaan natalan ke } \\
\text { gereja, hanya menghormati dengan empati } \\
\text { merayakannya. }\end{array}$ & $\begin{array}{l}\text { - Ritual: pergi ke gereja setiap malam minggu, } \\
\text { - Kadangkala ikut shaum Ramadhan kadang } \\
\text { tidak, namun selalu mempersiapkan sahur dan } \\
\text { buka puasa bagi keluarga yang shaum Ramadhan. } \\
\text { - berdoa di gereja (bernyanyi di gereja) memakai } \\
\text { gamelan } \\
\text { - Ikut merayakan lebaran dengan suami atau } \\
\text { istri pergi bersalaman kepada handai tolan dan } \\
\text { tetangga. Menghadiri jika ada Hari besar Islam }\end{array}$ \\
\hline $\begin{array}{l}\text { - Pakaian: baju Muslim, baju koko, kopiah haji, } \\
\text { untuk jum'atan laki-laki, mukena alat salat wanita, } \\
\text { sajadah, tasbih, pakaian kampret hitam bagi } \\
\text { laki-laki (jika ada perkawinan dalam keluarga), } \\
\text { pakaian Muslim dan kerudung jika pergi ke } \\
\text { pengajian. }\end{array}$ & $\begin{array}{l}\text { - Pakaian: kalung salib, pakaian kampret hitam } \\
\text { (dipakai oleh laki-laki jika ada perkawinan dalam } \\
\text { keluarga), kerudung jika ada yang undang } \\
\text { kepengajian (dipakai oleh perempuan), atau jika } \\
\text { ada yang meninggal }\end{array}$ \\
\hline $\begin{array}{l}\text { - Simbol: gambar masjid, gambar lafaz Allah, dan } \\
\text { lafaz Muhammad Saw. di gantung di dinding ruang } \\
\text { tamu untuk menandakan saya orang Islam yang } \\
\text { patuh dan taat. }\end{array}$ & $\begin{array}{l}\text { - Simbol: gambar salib, pohon cemara (pohon } \\
\text { natal), pernak-pernik untuk perayaan natal, lilin, } \\
\text { patung Yesus dan salib, patung Bunda Maria, } \\
\text { simbol ini adalah lambang kesucian bahwa } \\
\text { Yesus bersama kita, dibingkai, lalu diletakkan di } \\
\text { ruang keluarga, supaya keluarga lebih mudah } \\
\text { mengenalinya dan mencintainya }\end{array}$ \\
\hline $\begin{array}{l}\text { - Makanan: makanan khas Lebaran "ketupat } \\
\text { Lebaran" dll. disediakan untuk menjamu orang } \\
\text { yang berlebaran. }\end{array}$ & $\begin{array}{l}\text { - Makanan: makanan khas natalan, roti, kue-kue } \\
\text { dll. diadakan setiap jamuan Hari Natal }\end{array}$ \\
\hline $\begin{array}{l}\text { - Tanda kedukaan: Bendera dari kertas warna } \\
\text { kuning untuk pertanda bahwa ada yang meninggal } \\
\text { dunia } \\
\text { - Memakai pakaian kedukaaan (kerudung) }\end{array}$ & $\begin{array}{l}\text { - Tanda kedukaan: Bendera dari kertas warna } \\
\text { kuning untuk pertanda bahwa ada yang meninggal } \\
\text { dunia } \\
\text { - Memakai pakaian kerudung kedukaan/selendang }\end{array}$ \\
\hline
\end{tabular}




\section{Faktor Pendukung dan Penghambat Kerukunan dalam Keluarga Berbeda Agama}

\begin{tabular}{|c|c|}
\hline Faktor Pendukung & Faktor Penghambat \\
\hline $\begin{array}{l}\text { - Saling menghormati, mengayomi, toleransi } \\
\text { yang tinggi }\end{array}$ & $\begin{array}{l}\text { - Menghindari pembicaraan mengenai keyakinan. } \\
\text {-Ketidak terbukaan kedua belah pihak suami-istri } \\
\text { dalam membicarakan hal keyakinan masing- } \\
\text { masing }\end{array}$ \\
\hline $\begin{array}{l}\text { - Saling menolong memberikan santunan, } \\
\text { membantu memberikan pinjaman, saling } \\
\text { mengirim makanan baik hari-hari biasa maupun } \\
\text { hari besar umat beragama }\end{array}$ & $\begin{array}{l}\text { - Dalam pendidikan agama, tidak memberikan } \\
\text { ketegasan yang harus dianut oleh anak-anak }\end{array}$ \\
\hline $\begin{array}{l}\text { - Faktor-faktor pendukung dan kerjasama antar } \\
\text { warga; pemakaman, pernikahan, kerja bakti, } \\
\text { sosial kemasyarakatan seperti membersihkan } \\
\text { gorong-gorong, jalan, menjadi aparat setempat, } \\
\text { dan kerja sama dalam membantu tetangga yang } \\
\text { terkena musibah atau bencana. }\end{array}$ & $\begin{array}{l}\text { - Pembelajaran ilmu agama diberikan oleh kedua } \\
\text { orang tua mereka, dengan menyekolahkan ke } \\
\text { sekolah sore (untuk belajar Islam) dan sekolah } \\
\text { Rabu (untuk belajar Kristen Katolik). Anak usia } \\
\text { dini menerima pendidikan non formal dari dua } \\
\text { keyakinan. }\end{array}$ \\
\hline $\begin{array}{l}\text { - Masyarakat setempat mempunyai tradisi } \\
\text { kebersamaan: sedekah kuburan "kuburan Capar", } \\
\text { "kuburan Ki Buyut Putih", syukuran musim hujan }\end{array}$ & $\begin{array}{l}\text { - Setelah dewasa dipersilakan untuk memilih } \\
\text { agama masing-masing sesuai keyakinan dan } \\
\text { kehendak hati dengan tanggung jawab. }\end{array}$ \\
\hline
\end{tabular}

muslim laki-laki atau perempuan makanan khas lebaran untuk muslim dan makanan khas natalan bagi Keristen Protestan, hal ini merupakan cerminan dari simbol-simbol yang ada pada budaya mereka. Budaya itu didasarkan pada simbol. Hubungan antara budaya dan simbol menjadi jelas ketika Ferraro menuliskan dalam (Larry A.Samover, 2010: 46) "Simbol mengikat orang yang mungkin saja bukanlah bagian dari suatu kelompok yang bersatu." Simbol memungkinkan orang untuk membungkus, menyimpan, dan menyebarkannya. Pikiran, buku, gambar, film, tulisan tentang agama, video, aksesori computer, dan sebagainya memungkinkan suatu budaya melestarikan apa yang dianggap penting dan berharga untuk diturunkan.

Demikian pula Macionis menyatakan (dalam Larry A.Samovar, 2010: 46)

\begin{abstract}
"simbol merupakan segala sesuatu yang mengandung makna khusus yang diketahui oleh orang-orang yang menyebarkan budaya" demikian simbol-simbol yang ada pada keluarga berbeda agama.

Beberapa faktor pendukung dalam kerukunan keluarga berbeda agama, dapat dilihat, mereka saling mengayomi, menghormati dengan penuh toleransi yang tinggi. Selama ini kampung desa Sidawangi aman-aman saja, tidak ada gejolak yang diakibatkan oleh keberadaan perbedaan agama dalam sebuah keluarga.
\end{abstract}

Faktor pendukung lainnya ialah bahwa pada dasarnya keluarga berbeda agama toleransinya tinggi, mereka saling tolong menolong, empati, bukan saja hanya di dalam keluarga, namun dilakukan dengan baik kepada sesama tetangga, dengan saling tukar makanan, saling mengirim makanan bila ada peringatan hari-hari besar agama. Seperti jika ada Mauludan atau Rajaban, mereka mengirim berkat untuk tetangga lainnya walaupun yang mengirim bukan seorang Muslim. Kemudian, bukan hanya hari besar agama tertentu, tetapi hari biasa pun saling menolong dengan memberikan sedekah atau santunan ala kadarnya kepada tetangga yang membutuhkan.

Tradisi sosial kemasyarakatan yang terdapat di Desa Sidawangi yang sudah beberapa tahun ini berlangsung setiap tahunnya yaitu "Sedekah Kuburan" dan "Syukuran Musim Penghujan." Sedekah Kuburan diselengarakan di komplek kuburan yaitu "Kuburan Capar,", kompleks Kuburan Ki Buyut Putih, dengan acara membaca doa dan membaca mantera yang dipimpin sesepuh, lalu diadakan makan-makan bersama, makan 'berkat' yang berisi nasi, telor ayam, laukpauk. Hal ini terselenggara karena inisiasi masyarakat yang difasilitasi oleh aparat desa setempat. Sedangkan Musim "Syukuran Musim Hujan" diselenggarakan bila musim penghujan telah datang, diselenggarakan atau diadakan di setiap tempat mata air dan di setiap masjid.

Kegiatan tersebut diselenggarakan khusus untuk masyarakat setempat, dalam rangka mempererat silaturahmi dan 
kebersamaan antarwarga. Dalam acara ini diadakan doa, makan bersama, dll. sehingga masyarakat luas menikmati berbagai hidangan yang ada (dengan masakan tradisional masyarakat setempat yang dibuat oleh dan untuk masyarakat).

Faktor-faktor pendukung dan kerjasama antar warga seperti pemakaman, pernikahan, kerja bakti sosial kemasyarakatan seperti membersihkan gorong-gorong, jalan, menjadi aparat setempat, dan kerjasama dalam membantu tetangga yang terkena musibah atau bencana.

Faktor penghambat yang utama ialah adanya ketidakterbukaan kedua belah pihak suami-istri dalam membicarakan hal keyakinan masing-masing. Bila salah satu dari kedua belah pihak (suami adan istri) terbuka dikhawatirkan menyebabkan adanya konflik internal. Hal ini diakui oleh semua pasangan keluarga berbeda agama, sehingga hal ini dihindari dengan alasan "memilih jodoh" pun dari awalnya sudah berbeda keyakinan "mengapa diungkit-ungkit lagi," demikian penjelasan mereka.

Sosiologi Max Weber telah sedikit menjelaskan bahwa interpretasi agama ini merupakan aktivitas simbolis independen, agama secara signifikan memengaruhi perilaku individual dan merupakan penafsiran manusia yang paling penting tentang kondisi eksistensial seorang individu. Max Weber memberi penekanan khusus juga terhadap teodesi religius dan terhadap agama sebagai "perilaku-sarat makna" (Turner, 2012:28)

Komunikasi dalam sebuah keluarga sebagai subsistem dari masyarakat sangat mempunyai fungsi yang berarti dalam menanamkan nilai-nilai kepercayaan, tradisi, kesetaraan dalam setiap aktivitas dalam berinteraksi antar anggota keluarga. Seyogianya antar keluarga inti memelihara interaksi secara terbuka dalam hal apapun baik yang menyenangkan maupun yang tidak menyenangkan, selaras dengan pernyataan (Jeanny, 2014:201) sesuai tujuan pokok komunikasi ialah memprakarsai dan memelihara interaksi antara satu anggota dengan anggota lainnya, sehingga tercipta komunikasi yang efektif. Dengan demikian, komunikasi pada keluarga dapat membicarakan hal-hal yang terjadi pada setiap individu anggota keluarga, termasuk hal tentang kepercayaan, nilai-nilai yang seyogianya wajib dimiliki anak, agar dapat mengambil solusi terbaik.
Faktor penghambat lainnya dalam komunikasi antarpribadi pada keluarga berbeda agama adalah hal pendidikan agama, tidak memberikan ketegasan mana yang harus dianut oleh anak-anak dari keluarga berbeda agama. Sedangkan dalam aturan masing-masing agama, baik Islam maupun Kristen Katolik, mengisyaratkan bahwa "Pendidikan agama adalah hal yang esensi merupakan pondasi bagi kehidupan" sehingga harus ditanamkan sekuat mungkin agar kelak menjadi manusia berkarakter. Karakter akan terinternalisasikan dalam kehidupan manakala sejak dini pendidikan karakter sudah diajarkan melalui pembiasaan orangtua dan atau lingkungan.

Sebagaimana dijelaskan Idris Apandi, (2014: 14), pendidikan pada dasarnya adalah suatu proses untuk menciptakan kedewasaan pada manusia. Proses yang harus dilalui tersebut membutuhkan waktu lama, sebab hal yang akan dapat dikembangkan bukan hanya kognitif semata atau perkembangan tubuh semata, namun lebih jauh lagi, yaitu berbagai aspek kehidupan, yang termasuk di dalamnya kepercayaan, nilai-nilai ketuhanan. Keluarga dan sekolah seharusnya menjadi tempat menginternalisasikan nilai-nilai kepercayaaan, kebaikan, toleransi, solidaritas, saling menghargai sesama.

Demikian pula mengenai "pernikahan" merupakan hak azasi manusia, sebagaimana pula tentang "beragama/mengenai keyakinan" tidak boleh dipaksa, hal ini merupakan hak azasi manusia menurut subjek peneliti.

Fitur lain dari semua budaya adalah agama. Lebih khusus lagi, menurut Parkes, Laungani, dan Young, "memiliki agama yang dominan dan terorganisasi dimana aktivitas dan kepercayaan mencolok (upacara, ritual, hal-hal tabu, dan perayaan) dapat berarti dan kuasa" (Samovar, 2010: 29). Dalam hal ini, keluarga berbeda agama tidak menjadikan salah satu keyakinan menjadi hal dominan dalam hidup mereka, tetapi mengorganisasinya dengan keyakinan keduanya (Islam-Kristen-Protestan) dengan mengikutsertakan putra-putrinya mengikuti pendidikan agama keduanya, misalnya, hari Rabu mengikuti sekolah Rabu (Kristen) dan setiap sore mengikutsertakan sekolah agama sore (Islam). Pengaruh agama dapat dilihat dari semua jalinan budaya, karena hal itu berfungsi dasar. Ferraro (dalam Samovar, 2010: 29) menyatakan bahwa fungsi ini meliputi kontrol sosial, penyelesaian konflik, penguatan kelompok solidaritas, penjelasan 
dari sesuatu yang sulit dijelaskan, dan dukungan emosional.

\section{Langkah dalam Meminimalisasi Hambatan}

Langkah untuk meminimalisasi hambatan komunikasi pada keluarga berbeda agama sebagaimana dilakukan dengan menghindari pembicaraan secara terbuka dan terang-terangan tentang keyakinan masingmasing, namun dengan saling pengertian satu dengan lainnya, empati, suportif dan kebersamaan hal ini dapat meminimalisasi hambatan dalam komunikasi antarpribadi dalam keluarga yang berbeda agama.

Selain hal di atas, secara sosial kemasyarakatan di Desa Sidawangi selalu diadakan pesta rakyat yang bertujuan untuk meminimalisasi disintegrasi antar warga dengan mengadakan acara "Sedekah Kuburan" dan "Syukuran datangnya hujan, yang diadakan di setiap mata air dan masjid."

"Sedekah Kuburan" yaitu sedekah masyarakat desa Sidawangi dilaksanakan di palataran 'Kuburan Capar', yaitu sebuah kuburan 'Kuburan Buyut Putih'. Adapun acara yang dilangsungkan yaitu pengajian, solawatan, berdoa bersama-sama, makanmakanan tumpeng yang merupakan berkat yang dibuat oleh masyarakat yang berisi telur, ayam, nasi, lauk pauk, sayuran dan buahbuahan. Masyarakat berkumpul bersamasama warga," diadakan satu tahun sekali pada hari jadi Desa Sidawangi.

Selain acara 'syukuran datangnya musim penghujan' yang di adakan di setiap mata air, dan di setiap masjid (di masjid dan di mata air). Acara ini dikoordinisasi oleh kepala desa dengan panitia para aparat desa serta masyarakat umum. Acara ini dipimpin oleh seseorang yang dituakan.

Acara-acara ritual tersebut menjadi salah satu perekat sosial, sebagaimana dalam definisi agama di sebutkan E.S.P Haynes dalam Kahmad (2009:161), yang berpendapat bahwa agama sebagai "suatu teori tentang hubungan manusia dengan alam raya," kebersamaan dalam menjalankan ritual alam yang diselenggarakan masyarakat di desa tersebut menandakan keharmonisan alam dan masyarakat yang dijunjung tinggi, hal ini pun senada dengan masyarakat yang berada di lingkungan Desa Sidawangi, perbedaan agama tidak menjadi penghalang dalam tolong menolong dan menjalankan budayanya, sebagaimana pernyataan
Kahmad, (2009: 166), supaya tidak terjebak pada pemahaman yang sempit. Alangkah baiknya jika kita kembali bahwa penegasan Nabi Muhammad Saw yang menyatakan bahwa sebaik-baiknya agama di sisi Allah adalah al-hanifiyyat-al-samhah, semangat kebenaran yang lapang dan terbuka; agama yang bersemangat kebenaran dan lapang serta terbuka untuk menolong manusia. Artinya, dalam hal ini masyarakat yang berbeda keyakinan sama-sama bersemangat lapang dan terbuka untuk saling menolong, secara sosial kemasyarakatan.

\section{Simpulan dan Saran}

Peran komunikasi antarpersona dalam keluarga berbeda agama, berperan efektif dalam beberapa hal, seperti saling keterbukaan (bukan dalam hal prinsip keyakinan), empati, saling mendukung, objektif dan kesamaan satu dengan lainnya antara suami istri. Selain hal tersebut, suami istri saling inisiasi dalam berkomunikasi, mengungkap informasi mengenai pasangan, membantu mengungkapkan persamaan dan perbedaan (perbedaan bukan dalam hal keyakinan). Keduanya merupakan satu unit, bukan merupakan individu yang terpisah. "Pendidikan Agama" keluarga berbeda agama tidak memberikan ketegasan tentang pendidikan agama yang harus di jadikan pedoman dalam hidup. Orang tua memberikan kebebasan untuk memilih.

Makna simbol-simbol dan interaksi dalam komunikasi antarpersona pada keluarga berbeda agama seperti ritual, kalung salib, pakaian adat kampret hitam, gambar masjid, gambar gereja, pohon natal, pernakpernik natal, peralatan salat baik yang dipakai Muslim laki-laki atau perempuan, makanan khas lebaran untuk Muslim dan makanan khas natalan bagi Kristen-Protestan, hal ini merupakan cerminan dari simbol-simbol yang ada pada budaya mereka.

Faktor-faktor yang mendukung dan menghambat kerukunan dalam keluarga berbeda agama. Faktor pendukung dalam keluarga berbeda agama yaitu saling terbuka dalam komunikasi antarpribadi dalam bukan hal ranah keyakinan, saling menghormati, saling empati dan saling mendukung antar individu dalam keluarga. Sedangkan hal-hal yang mendukung kerukunan di masyarakat setempat, yaitu masyarakat Desa Sidawangi sering bergotong royong antar warga, saling berkirim makanan, dan saling mendukung 
dalam hal-hal kemasyarakatan dengan baik, seperti jika terdapat musibah yang menimpa warga setempat.

Faktor penghambatnya yaitu keluarga berbeda agama sering menghindari "keterbukaan berbicara tentang keyakinan mereka masing-masing," karena hal ini, menurut mereka, akan menjadikan disintegrasi atau konflik dalam keluarga mereka.

Aktualisasi peran pemuka agama yang lebih intens dalam memberikan pembinaan serta pembelajaran keberagamaan kemasyarakat agar lebih diinstensifkan.

\section{Daftar Pustaka}

Apandi, Idris. (2015). Revolusi Karakter. Bandung: Fajar Media.

Gudykunst, W.B. \& Stella Ting Toomey, (2003). Culture and Interpersonal Communication. New Burry Park, Beverly Hills, CA: Sage Publications.

Jeanny Maria Fatimah. (2014). "Komunikasi Keluarga Meningkatkan Ases Pendidikan bagi Kesetaraan Anak Perempuan dalam Lingkaran kemiskinan", Mimbar Jurnal Sosial dan Pembangunan Unisba, Vol 30, N0. 2, pp127-270.

Jandt, Fred E. (2004), An Introduction to Intercultural Communication, Identities in a Global Community, Fourth Edition. California:Sage Publication,

KJ Veeger. (1985), Realitas Sosial, Refleksi Filsafat Sosial atas Hubungan Individu - Masyarakat dalam Cakrawala Sejarah Sosiologi. Jakarta: Gramedia.

Kahmad, Dadang. (2009). Sosiologi Agama, Rosda Karya: Bandung.

Knapp, M.L,. (1978). Social intercourse: From greeting to goodbye. Boston: Allyn and Balcon.
Kuswarno, Engkus, (2009). Metodologi Penelitian Komunikasi Fenomenologi, Konsepsi dan Contoh penelitian. Bandung:Widya Padjadjaran.

Kurniati, Nia. (2001), Tesis: Pengaruh Karakteristik Sosiodemografi dan Jarak Sosial terhadap Efektivitas Komunikasi Antaretnik, Unpad:PPS

Littlejohn, W. Stephen, Foss, Karen A. (2001). Theories of Human Communication $6^{\text {th }}$ Edition, Belmont CA, Wadsworth, N/A

Liliweri, Alo. (2009). Dasar-Dasar Komunikasi Antarbudaya. Yogyakarta: Pustaka Pelajar Offset.

Mulyana, Deddy. (2001), Pengantar Ilmu Komunikasi. Bandung:Rosda Karya.

Mulyana, Deddy. (2010). Metodologi Penelitian Kualitatif, Paradigma Baru IImu Komunikasi dan Ilmu sosial. Bandung: Rosdakarya.

Masykur, Ali. (2005). Artikel Ilmiah, tentang Pola Komunikasi Antar Umat Beragama. Banten: IAIN Sultan Maulana Hasanuddin.

Martin, N. Judith dan Nakayama, Thomas K. (2004). Intercultural Communication in Contex, Third Edition, New York, America.

Samovar. A.Larry dkk. (2010). Komunikasi Lintas Budaya, edisi 7. Jakarta: Salemba Humaniora

Sudikin,B. (2002). Metode Penelitian Kualitatif Perspektif Mikro. Insan Cendikia.

Sugiono. (2012). Metode Penelitian Kombinasi (Mixed Methods). Bandung: Alpabeta.

Tubbs, Stewart L. \& Sylvia Moss. (2001). Human Communication. New York: McGraw-Hill.

Turner. S Bryan.( 2012). Relasi Agama dan Teori Sosial Komtemporer.Yoyakarta: IRCiSod Sosiological 33

Osborne, Cecil G. (1988). The Art of Understanding Your Mate. Michigan: Zondervan Publishing House Grand Rapids.

Sumber Lain:

Koran Kompas 28/5/2009. 